\title{
Four Admirals and the Navy: Unification, Trudeau, NDHQ, and NATO
}

\section{J.L. Granatstein}

In 1987, Robert Bothwell of the University of Toronto and I were doing the research for a book on the defence and foreign policies of Pierre Trudeau's government. The book, the concluding volume in the Canadian Institute of International Affairs' "Canada in World Affairs" series, was duly published in 1990 by the University of Toronto Press under the title Pirouette: Pierre Trudeau and Canadian Foreign Policy.

Professor Bothwell and I went to Victoria, BC, in September that year to interview a number of key military, political, and bureaucratic players in the Trudeau period, including four retired senior naval officers. Our interest was in the impact of Trudeau's defence policy on the Canadian Forces, not least the Navy, on Canada's relations with the North Atlantic Treaty Organization, and on National Defence Headquarters and how the headquarters had reacted to unification, civilianization, and the people whose roles and personalities had helped to shape events. We interviewed four retired admirals in two days, and Bothwell wrote up one interview memorandum (on Vice-Admiral D. Alan Collins); I prepared the memoranda on the other three retired officers. All the interviews were on the record, and copies of the memoranda, along with some two hundred others, are in my papers at the York University Archives in Toronto and in Professor Bothwell's papers at the University of Toronto Archives.

The four admirals we interviewed were Vice-Admiral Collins (24 September 1987), Rear-Admiral Robert "Bobbie" Murdoch (25 September 1987), Rear-Admiral Michael Martin (24 September 1987), and Rear-Admiral Richard Leir (24 September 1987).

Highly regarded by his peers, Collins had joined in 1940 and risen through the "pusser" side of the Royal Canadian Navy, serving among other positions as secretary to the chief of the naval staff in 1946. By 1967 he was director general supply at NDHQ, then deputy chief logistics in 1970, chief technical services in 1972, and deputy chief of the defence staff (support) in 1972. In 1973, he went to NATO as military representative, and in 1979, after working in industry, he became assistant secretary-general for infrastructure at NATO headquarters. He died in 2005.

Murdoch had joined the RCN in 1936, served with the Royal Navy during the war and as a communications specialist rose through the postwar Navy. He was director of naval intelligence in 1961, director general plans in 1964, deputy chief (plans) in 1966, and he was posted to NATO as military representative in 1967 where the Trudeau defence 
cuts of 1969 had to be "explained" to Canada's allies. His last posting was as commander of the Canadian Defence Educational Establishment in 1971. Murdoch died in 2004.

Admiral Martin joined the $\mathrm{RCN}$ in 1944, and rose through the postwar RCN. He commanded Skeena in 1963, was deputy chief (combat readiness) at Maritime Command in 1967, commander of the $2^{\text {nd }}$ Destroyer Squadron in 1970, and commanded on the West Coast in 1977 where he was "loved," as one officer recalled.

Dick Leir was "a unique character" with a great reputation for taking "no lip from anyone," one officer recalled, who joined the RCN in 1940 and survived the sinking of HMS Prince of Wales in 1942 and three years as a Japanese POW. He served off Korea, commanded Skeena in 1962, led an escort squadron, and commanded the Canadian ASW Carrier Group. He became director general recruiting in 1968, commander Maritime Forces Pacific, and finally chief of maritime

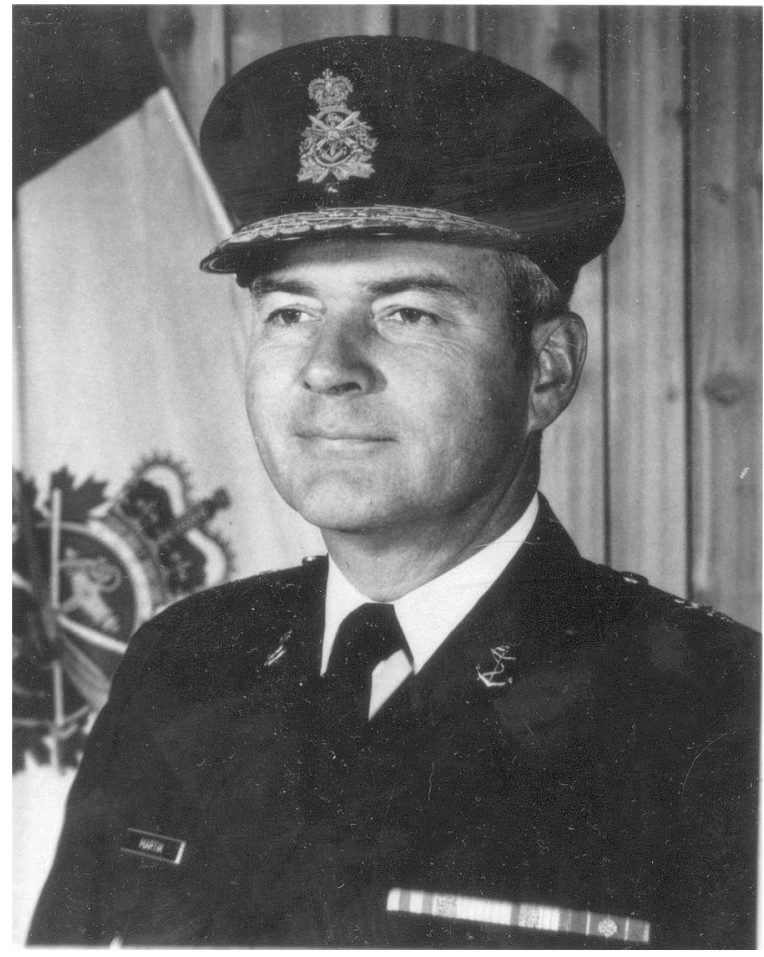

Illustration 1: Rear-Admiral Michael Martin. Courtesy Department of National Defence. operations at NDHQ from 1973-75. His reputation at NDHQ was high for "fighting the bureaucracy and fools."

As might be expected and as will be readily apparent, the views expressed by the admirals differed widely on many subjects, not least on personalities. But all were in command and administrative positions during some of the most difficult periods in Canadian military and naval history, and all held strong views.

The interview material has been grouped into four sections: The Impact of Unification; The Defence Review; At NDHQ; and At NATO. Each interviewee is identified, and their comments have been grouped to create a more coherent narrative, while minor amendments have been made to correct grammatical slips, spelling errors, and mixups in dates. Not all spoke on each subject.

\section{The Impact of Unification}

Adm. Martin: There was some surprise at the rapidity of promotion of some, like [Ralph] Hennessy, who was nonetheless respected, and [Robert] Falls. Those who stayed tried to protect the RCN and to keep it as intact as possible. Admiral [John "Scruffy"] O'Brien led the fight. Badges etc. were important—needed to make people 
feel important and to get the best effort from in a war situation.

But after the unification fight was lost, the RCN went into a lethargic state. He would go to a mess dinner and find that officers had forgotten how to run it the Navy way. When he went to a PPCLI [Princess Patricia's Canadian Light Infantry] dinner, he saw they hadn't forgotten, had designed their own mess kit, and had a handbook of traditions. This led him in 1979 to commission a similar book for the Navy.

Unification mixed people from the other services on ships. He thought this worked well, and called it "integration." The problem was to keep the "tin boxes" going. This was so complicated only a naval officer could be chief of staff in Halifax and Victoria. The problem on the West Coast was made worse because Halifax was HQ of Maritime Command.

Adm. Murdoch: [Defence Minister Paul] Hellyer, he said, had worked out the businessman's way of rationalizing the Canadian Forces, but Treasury Board had not provided the money to get the capital equipment. He objected to the insensitivity with which unification was done but not to the idea. Something had to be done about costs and about the separate organizations....

Adm. Leir: Unification had a negative impact on training because, for the Navy, training was carried out far from the sea. He was Director General Training and thought it didn't work. You couldn't have an army cook on a ship. The cook wouldn't be on the team and couldn't handle other roles. Moreover, the reduction in trades classifications from 300 to 150 or so was largely bogus. In technical areas, one environment's needs were different from the others, and the result was that the Navy had to run unofficial training schools on those emerging from the central schools. This raised costs, although there were savings on accountants, cooks, etc. The supply side thought unification worked; the sharp end didn't. Leir conceded that equipment was ageing at the same time which also hurt.

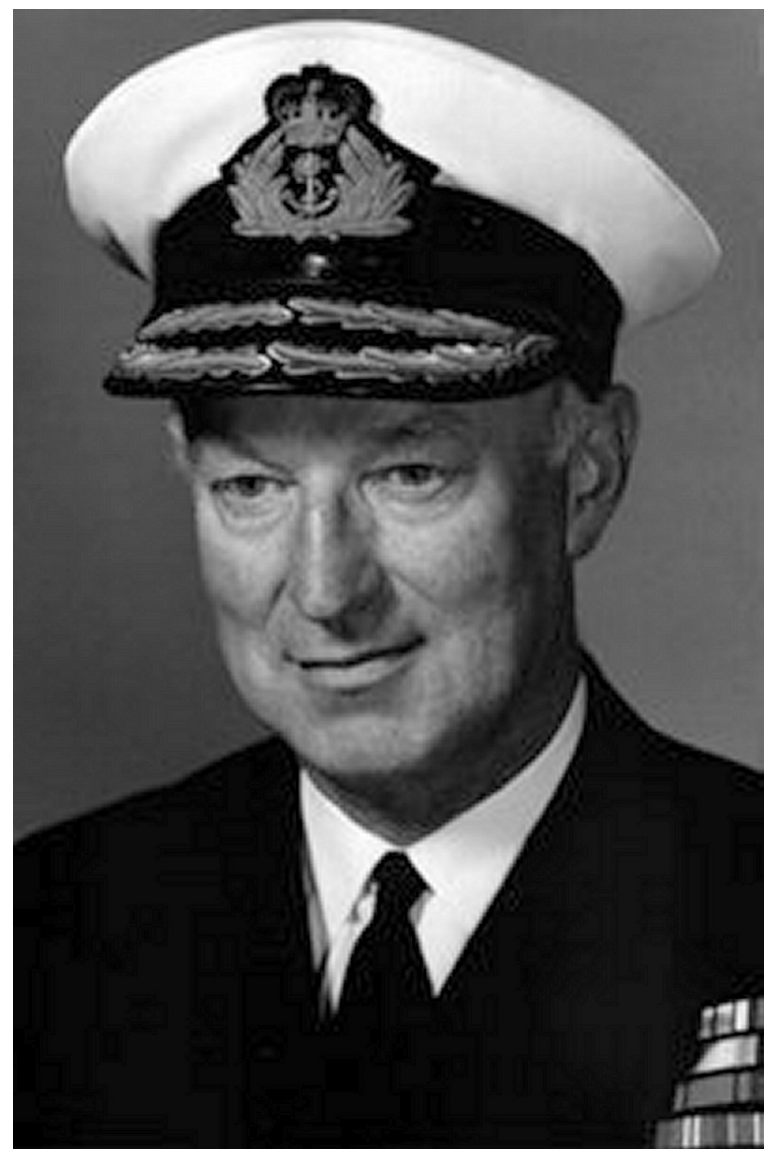

Illustration 2: Rear-Admiral Robert "Bobbie" Murdoch. Courtesy Department of National Defence. 


\section{Trudeau's Defence Review}

Adm. Murdoch: He was not surprised by the [Pierre] Trudeau [government's defence] review [of 1969]. He realized the Prime Minister was not at ease with the military. And he felt [Trudeau] could have lived with a demilitarized country. Even so, Joe Clark was more uncomfortable with the military than Trudeau.

He agreed DND had misjudged Trudeau with its defence review paper [that had argued for the CF to keep doing what it had been doing] — bad tactics. The military was always wedded to the status quo and tended to be gutless - and wedded to their pensions. What was surprising was that so few raised their voices against Trudeau's NATO decision, and it is surprising that the Assistant Deputy Ministers said nothing too. Trudeau tried no nonsense with NORAD and the PJBD and continental defence - on this he was sensitive.

[Defence Minister Léo] Cadieux was too nice, he said. He wanted to stay popular. It was hopeless to pit this man of softness against Trudeau's steel.

Adm. Leir: The Defence Review plucked the heart out of the Navy by getting rid of the Bonaventure. Why was it scrapped? To reduce the strength of the CF and especially Navy strength. The argument went that naval air was unnecessary in a unified force, and this was pushed by the Air Force. Leir thought that a seaborne force was essentially a foreign policy problem once at sea and, added to this, the RCN had been mistrusted by government as a prickly lot. The cuts hurt because the carrier/ASW force was the best in NATO pre-1968 and level with the US and UK in technique and equipment. The result was that efficiency (and budget) dropped...The effect of these cuts on Canadian stature was substantial. We lost our position with NATO and the US. When he attended Chief of Naval Operations meetings in the US in 1973, he found cooled relations and intelligence doors closed, whether by intention or neglect.

Adm. Martin: The Defence Review was shattering to the CF because of the [personnel] strength cut. The HQ staffs tried hard to insulate the sharp end from the effects. The loss of the Bonaventure and a submarine on the West coast were very hard on the operational posture of the Navy. The carrier loss changed the Navy's capacity to function because the Navy needed aviation and because the RCN's high ASW capacity hinged on air use. The Navy no longer could control a piece of the ocean....

The US response to the weakening of the CF was "terribly polite" and they never said Canada wasn't pulling its weight. But, while they didn't exclude ships from exercises, the USN would not give Canada prime positions; we got less important roles at sea and in the air.

\section{At NDHQ}

Adm. Collins: He was Director-General Supply for the unified CF and eventually became Chief of Technical Services. 1968-71 was a particularly hard time but matters improved after Donald Macdonald, the Minister, brought in Sylvain Cloutier to be Deputy Minister [in September 1971]. In personal terms, he and his responsibilities flourished as Cloutier and [Chief of the Defence Staff General Jacques] Dextraze sawed 
off their parts of the Department. The position of Deputy Chief Supply was created and, despite an earlier run-in with Dextraze over unified uniforms, the CDS chose him for the job which was huge. He could have had "disproportionate" power, but instead he decided to blow the whistle on the position. The office of Assistant Deputy Minister Material was the result. From the civilian side it controlled a huge slice of the military....

Dextraze, who had headed Personnel once upon a time, insisted the Assistant Deputy Minister Personnel be military. So Cloutier traded it off: ADM Material would therefore be a civilian. Dextraze bought it....

Cloutier was "very clever, ruthless as hell, and ran rings around Jimmy Dextraze every morning before breakfast."...Macdonald gave him a free hand, with the object of making the military more responsive to civilian leadership. This was a change. In the old days the dictates of the Deputy Minister's office stopped at the office door. The [previous Deputy Ministers, like the] Elgin Armstrongs influenced the military by denying it authority to spend but otherwise there was "a distinct separation" between the civilian and military sides. Apart from money, the military was "running untrammelled." Cloutier's object was one Collins supported, though the consequences were farreaching. ... [He] rescued the military's capital budget and made sure it rose by 12 percent in real terms.

Back to Dextraze. "I don't think Jimmy Dextraze had the mental capacity to be Chief of the Defence Staff." He used to say he was a Corsican and boast that he could be more Machiavellian than Machiavelli. This was true: he was a man totally devoid of principle who believed he was imbued with principle. He may have been a brave fighting soldier; but he was totally out of his depth especially on NATO. Collins paused to think of something to Dextraze's credit, but couldn't....He was a total disaster as CDS.

Adm. Leir: He wasn't especially upset by civilianization at NDHQ. The RCN had always been lean at HQ with many civvies. He was leery of civilians doing planning, operations, intelligence work, and noted the military had tried to prevent this but lost. If the Minister decides on something, then it goes. The bad effect of this process was that it denied the military the chance

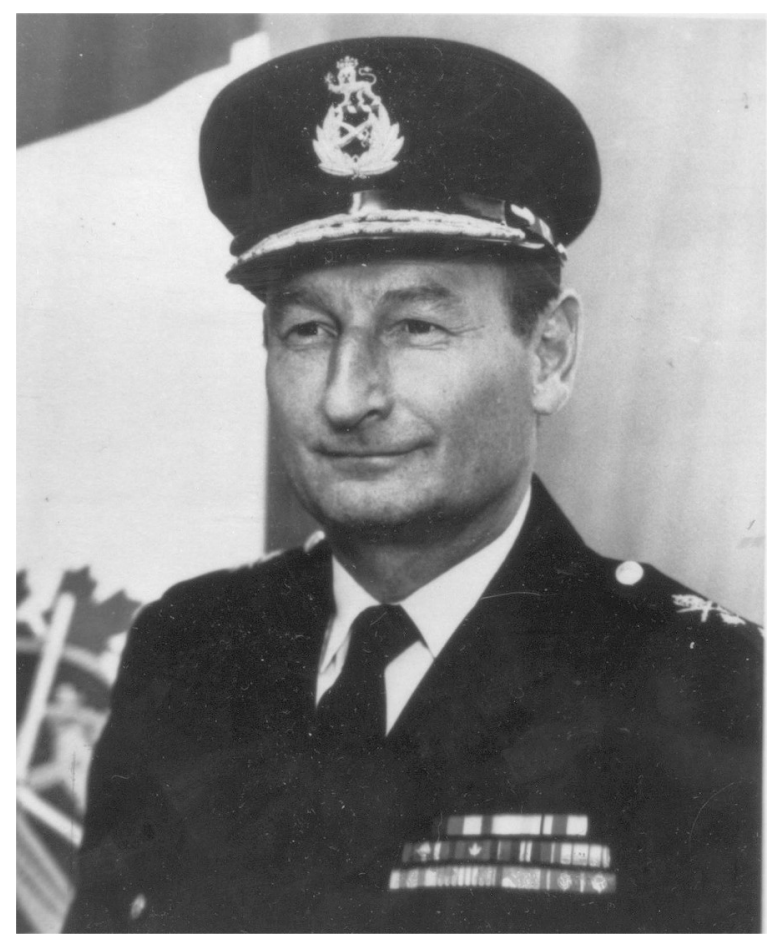

Illustration 3: Rear-Admiral Richard Leir. Courtesy Department of National Defence. 
to do the job; moreover, the civilian would be in the same job forever. The military chiefs, he said, basically allowed this to happen....

Why was NDHQ civilianized? The government wanted no interference from the military (or External Affairs), and the Prime Minister's Office was running defence and foreign policy. [Clerk of the Privy Council Michael] Pitfield "ran the railroad," and the PMO didn't like DND because Trudeau didn't like it....The real problem was money and the difficulty of getting it in the face of Trudeau's virtually anti-military policies. "He was a breaker, not a builder."...

The key move in civilianization was Donald Macdonald bringing in Cloutier. Cloutier was a problem, a man who might be able to run a grocery store. He was an extension of Pitfield's control, and Cloutier went his own way, not the way the military wanted. Cloutier regularly fended off NDHQ plans, knowing that Trudeau would eat them for breakfast. He was not really committed to defence. Leir admitted that Cloutier had managerial capacity and won over Dextraze. The two worked well together and maintained the status quo as Trudeau wanted. But the real problem remained that DND couldn't get the funding it needed to carry out its commitments, even though Cloutier knew Treasury Board well....

Dextraze was the right man for the time. He got on well with Trudeau, the PMO, and Cloutier. It was the "franco league." He kept the status quo intact and got whatever DND got because he was an old time Quebecker with friends in the right places.

As for Ministers, Macdonald was ambitious, Cadieux understood the military but was inefficient, but [Defence Minister James] Richardson was a breath of fresh air. NDHQ thought it could do things with him, but in the end he produced little in the way of hardware. No one thought him bright but "he liked the military." It was like a POW being beaten by his captors - if they called you "my friend," you felt so grateful. ...

On French Language Units: they were not less efficient but there got to be two navies. The first experiments had ships with one language or the other. On the French ships, internal orders were in French. But NATO operated in English. So it was tried to make the ships bilingual. Leir supported this although most of the Navy didn't. He thought bilingualism would help recruiting. He also said that holding to the 27 percent [francophone] figure on promotions was good because French Canadians hadn't had a fair chance in the RCN.

Adm. Murdoch: Dextraze was an emotional man and a bit crazy. He could be mean and spiteful, held strong opinions and wouldn't debate them. He would protest how brave he was. A fighting leader, but not [for] peacetime.

His relationship with Cloutier as Deputy wasn't healthy. Both were traders helping their favourites. Dextraze wasn't bright and was bad with people. Had to be watched at all times.

Adm. Martin: Dextraze was sharper than people thought, though not liked by all. He was an independent thinker who had Trudeau's ear, as all believed. He wasn't blamed for what went wrong. 


\section{At NATO}

Adm. Murdoch: He was in NATO as Military Representative [Canadian Military Representative to the Military Committee in Permanent Session] from 1967 to 1971 and spent much of the time with [Canada's Ambassador to NATO Ross] Campbell who, he said, "went to the wailing wall on a daily basis" with his forceful representations about the defence review. He, Murdoch, was asked only for occasional input from Ottawa. He didn't see the DND [defence review] paper before it went to Cabinet, and his role would not have been deemed important. His role? To explain Canadian policy in Brussels. After the decision on cuts, the planning was all done in Ottawa. The Supreme Allied Commander Europe's [SACEUR] role was to allocate space to the new Canadian force and to be unhappily diplomatic.

He described Campbell as bright and sharp, a little, angry man. He...liked that Ross could be silly if he thought that tack might work...He thought Campbell's postreview explosions were largely ignored in Ottawa, which was the worst thing one could do to Ross.

Ottawa was unable to see the peripheral impact of the NATO cuts. The Dutch military representative told him after Cadieux's May 1969 announcement that he bet this was the last contract that would go to Canadair from Holland. (Cadieux was so broken up by the Brussels meeting that he spent his 61st birthday in his bath feeling blue and wouldn't come to a dinner Murdoch had laid on.) The Dutch and others felt deserted and that Canada was paving the way for the US to follow suit. The view was that Canada was tearing the fabric of unity....

Having said that, Canada lost little clout because of the cuts. People still listened to him and talked to him before meetings. Canada held and still held an important place in Europe's heart and mind. His friends were sorry for him but wouldn't shoot the messenger. Canada's place in NATO's pecking order was higher than our contribution alone merited, in part because of our past role but also because of the effectiveness of the air, naval, and ground contribution. We did things well and got respect. Militarily, the Germans filled the gap in the Soest area [where the Canadian brigade had been based until it moved south and into a reserve role] very quickly and were not horrified by the Canadian action. Indeed he saw their attitudes changing in his Brussels time. In 1967 they were still tentative and accepted every request; by 1971 they were aware of their importance, becoming aggressive, and not unwilling to use their ability to replace the Canadians in Soest as an argument to get their way....

The NATO Military Committee was the representatives of the Chiefs of Staff in permanent session. The NATO Secretary-General [from 1971 to 1984], Joseph Luns, thought he was the Supremo - loud, overbearing, but able. Manlio Brosio, there to 1971, was gentle and statesmanlike, efficient but without the fire to carry the day. There was a tension between the military and civilian sides in NATO, not unlike that between National Defence and External Affairs.

Adm. Leir: On the quality of the CF: Canadians were never seen as second class, and in general we acted "larger than the size of our underwear" without embarrassment. 


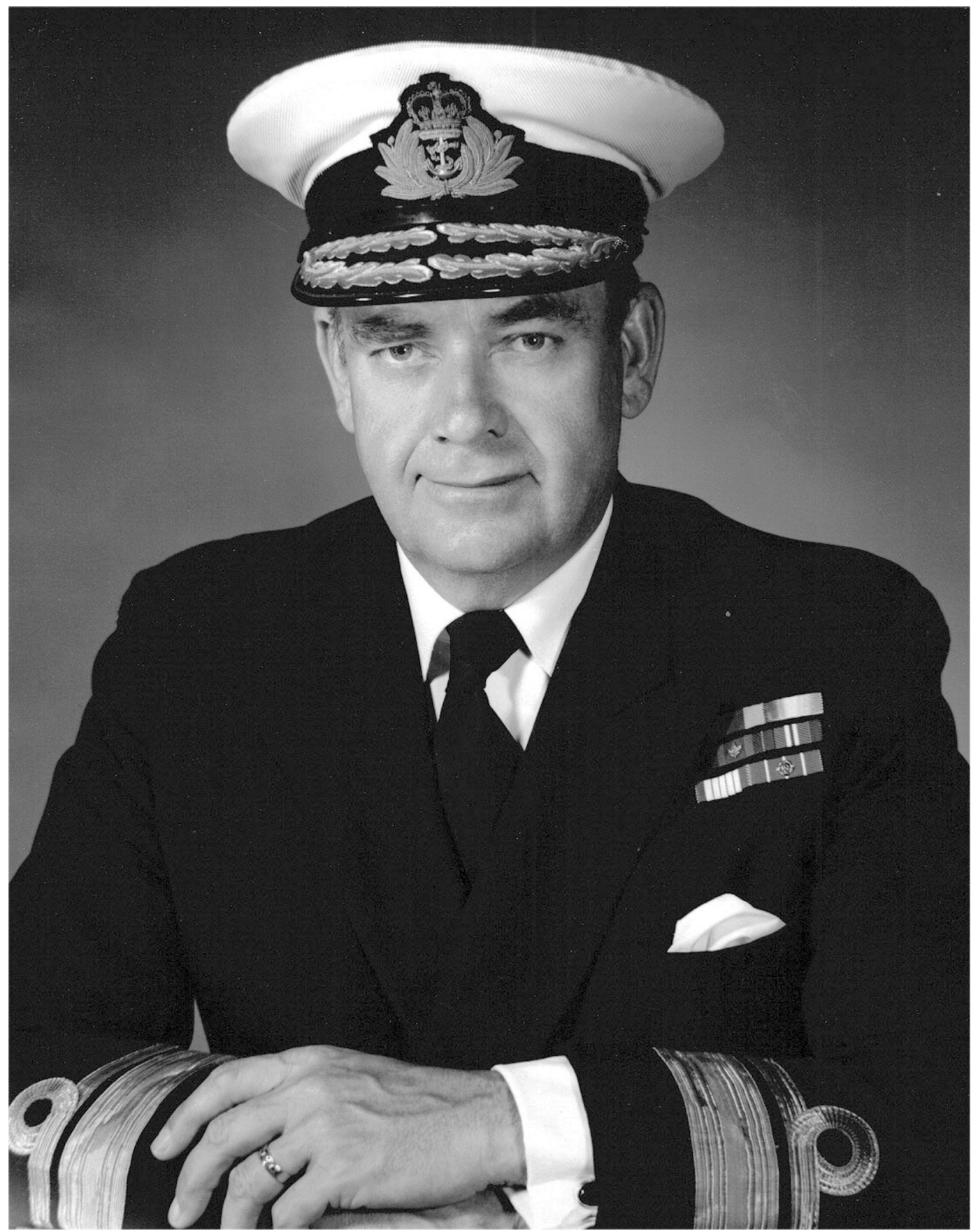

Illustration 4: Vice-Admiral D. Alan Collins RCN dressed as a Rear-Admiral (as he then was) before single service uniforms were abolished in the Regular Force to make way for the unified Green (1970).

Courtesy David Collins. 
We always got on with the US, but for years the Brits did the colonial number on us. The Royal Navy only began to take the RCN seriously in 1959-60 when an RCN force on exercise pummeled a new RN nuclear submarine.... The Canadian military, he said, had higher status outside Canada than in.

Adm. Collins: He had two whacks at NATO, Canadian Military Representative 1973-75 and as Assistant Secretary-General, 1979-84.

By 1973 the ruckus over Canada's cuts in 1969 had died down. "We were making a bit of an effort to do more," and Arthur Menzies, as Ambassador, "kept plugging away." On Collins' side, around the table "we were respected as keepers of our word, articulate," and as neutral, as not being involved in factions. This made Canada a good interlocutor. It also helped that Canada was the fifth-largest contributor to NATO's infrastructure....Canada had never been "entirely discredited" in NATO....

As to how he functioned on the Military Committee, Collins said he had "Canadian guidance on every item" on the agenda though Dextraze might say he could use his discretion within the limits of Canada's general policy....He and Menzies habitually pooled their information. Something not always done on other delegations. They used to dream of merging their organizations but it didn't happen.

In 1979, he was proposed by National Defence and External Affairs to be the Canadian candidate for Assistant Secretary-General for Infrastructure. He was not, therefore, a Canadian appointee, living in subsidized housing, but a NATO civil servant paid in Belgian francs. But he nevertheless stayed "close to my Ambassador for the common good." His staff were high quality....NATO floats on a substratum of talented British female secretaries, and the British always put forward wonderfully articulate candidates...The Americans and Canadians sent good people. The Germans ask only for the letter of their one- they do not seek a greater role.....Matters of strategy fell under the Assistant Secretary-General Political...[but] strategy is really the purview of the ministers....There are problems especially with SACEUR. SACEUR likes a special relationship with the Secretary-General, and may not find time for the Military Committee. This could place both in conflict with the Committee.... Luns as SecretaryGeneral was a very astute politician whose management style was interesting to put it mildly, but he stayed too long. ...He preferred unstructured meetings off the record in private....

He admired Trudeau: the Prime Minister did well by us. He was a "charismatic guy who drew the attention of the NATO Council when he was speaking... because of his sheer erudition and his fluency in two languages...." But his 1984 peace mission was a "non-event" at Brussels. It is true that the Canadian view of the USSR is softer than that of the US or UK or the Germans. "Far less hostile," is how he put it. 
